\title{
Model tests of a marine diesel engine powered by a fuel-alcohol mixture
}

\section{ARTICLE INFO}

Received: 13 July 2021

Revised: 29 October 2021

Accepted: 30 October 2021

Available online: 2 November 202
The paper presents the results of model and empirical tests conducted for a marine diesel engine fueled by a blend of $n$-butanol and diesel oil. The research were aimed at assessing the usefulness of the proprietary diesel engine model in conducting research on marine engines powered by alternative fuels to fossil fuels. The authors defined the measures of adequacy. On their basis, they assessed the adequacy of the mathematical model used.

The analysis of the results of the conducted research showed that the developed mathematical model is sufficiently adequate. Therefore, both the mathematical model and the computer program based on it will be used in further work on supplying marine engines with mixtures of diesel oil and biocomponents.

Key words: model tests, diesel engine, model adequacy assessment, alternative fuels, diagnostics

This is an open access article under the CC BY license (http://creativecommons.org/licenses/BY/4.0/)

\section{Introduction}

In recent years, a lot of emphasis has been put on the issue of air pollution with toxic compounds, and significant carbon dioxide emissions. It is reflected in the increasingly restrictive regulations on the emission of toxic compounds in transport.

Another important issue is the limited availability of fossil fuels. It can be expected that their prices will rise in the foreseeable future. This will result in an increase in the cost of people, and goods transportation.

One of the key modes of transportation is sea transport. This is mainly due to its versatility (practically any type of cargo, and the possibility of transporting bulky goods), and relatively low costs. For watercraft dedicated to the transport of people, and goods, the average lifetime is 29 years [15]. It follows, that most of the ships used in the world are equipped with reciprocating engines that do not meet the current stringent emission standards for toxic compounds. In most cases, these are two-stroke reciprocating engines adapted to run on light, and residual fuel. This results in the need to search for methods to reduce the emission of toxic compounds, and greenhouse resulting from the combustion of fossil fuels that are hydrocarbons. One of the methods of reducing the combustion of fossil fuels is the use of mixtures of the above-mentioned fuels, and broadly understood biocomponents. One of such biocomponents is n-butyl alcohol.

The paper presents the results of empirical, and model tests of a ship engine powered by a mixture of diesel oil, and n-butyl alcohol with volume fractions of 5, 10, and $15 \%$ n-butyl alcohol and 95, 90, and $85 \%$ diesel oil, respectively. The authors did not focus on residual fuels due to increasing restrictions on their use. This is mainly due to the fact that they are contaminated with sulfur compounds. The results of the research were presented in a statistical analysis, the purpose of which was, among others, to verify the proprietary engine model in relation to the real object. Positive verification should allow the model to be used in further work on alternative methods of powering marine engines. This will significantly reduce the research time, and cost.
The issue of the use of biocomponents in fuels is dealt with by many centers, both in Poland and abroad. Most of the research concerns fuels used in motor transport. For which the use of mixtures of fossil fuels and biocomponents has been the norm for many years [16, 18]. A large part of the research concerns their use in automotive spark ignition engines [2,5]. Research has also been carried out on the use of mixtures to power compression ignition engines $[6,9]$. Considerable interest (reflected in the number of publications) in the use of biocomponents in fuels used in road and rail transport results from European and national regulations $[15,16]$. However, there are few publications on the use of mixtures of fossil fuels and biocomponents in shipbuilding. Research on reducing the emission of toxic and greenhouse compounds (resulting from the combustion of fossil fuels) in the shipbuilding industry is enforced by the IMO (the so-called Sulfur Directive) and the European Union regulations, which impose restrictive sulfur oxide emission limits $[4,14]$.

\section{Research methodology}

The first stage of research was to develop a program for their implementation. It was presented in the form of an algorithm containing all the anticipated stages of the research [3, 11, 17] (Fig. 1).

\section{Model of the reciprocating diesel engine}

According to the research implementation program presented (Fig. 1), the first stage of the research was to develop a model of a reciprocating diesel engine [10, 11]. It was decided to use the model developed by the authors for the needs of diagnostic tests. It allows for the implementation of tests for a four-stroke reciprocating diesel engine. It is possible to conduct tests for both supercharged, and undercharged engines powered by virtually, any fuel containing hydrogen, carbon, nitrogen, oxygen, and sulfur. The engine may have a V-shaped, or linear arrangement of cylinders, and may contain from 1 to 8 cylinders. The model allows for any modification of the geometrical dimensions of the piston-crank system, i.e. cylinder diameter, connecting rod length, crankshaft crank length, and combustion chamber height. Moreover, it is possible to modify its structure in- 
fluencing the parameters of heat exchange between the medium inside the cylinder, and the cooling liquid and air. In addition, it is possible to modify the injection advance angle, the number and diameter of the injector holes, the opening and closing angles of the intake, and exhaust valves, their cross-sectional areas, and a number of other engine operating parameters.

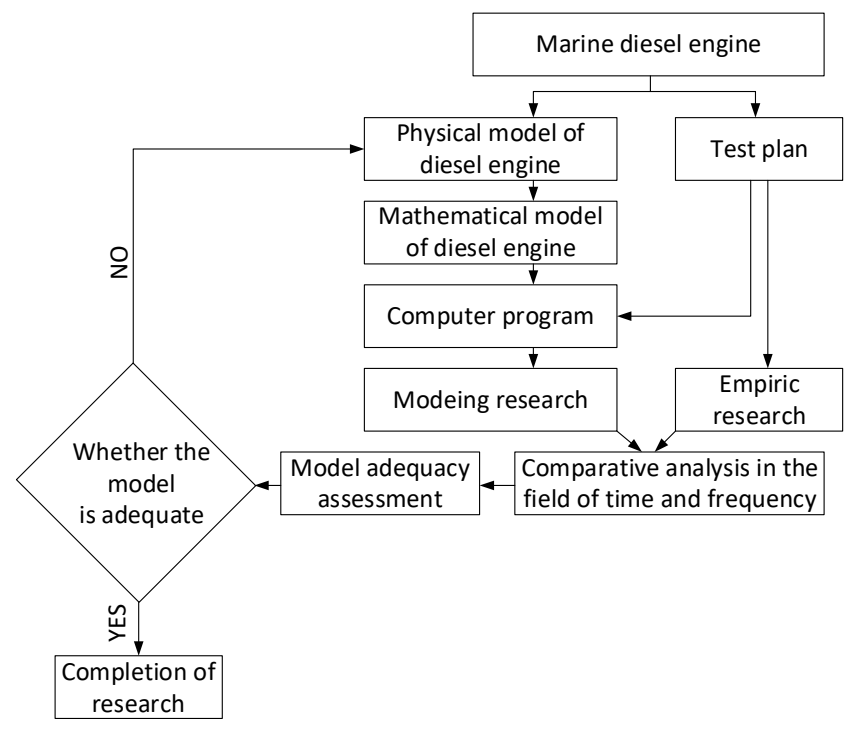

Fig. 1. Research program

The mathematical model of the marine engine, adopted for the purpose of the research, was assessed for adequacy during its development. The adequacy assessment consisted in conducting a comparative analysis of the selected measures for the modeled engine, and the real object. It was carried out in relation to laboratory engines installed in the Laboratory of the Engine Room Explitation - Sulzer engine type 6AL 20/24, and in the Laboratory of Marine Electrical Equipment - engine licensed from Leyland, type 6SW400. All tests were carried out on standard diesel fuel with mass fractions of $87 \%$ carbon, and $13 \%$ hydrogen. As a result of the research, it was found that the model is qualitatively, and quantitatively adequate $[11,13]$.

\section{Research plan}

According to the algorithm presented in Fig. 1, a research plan was developed. It included the test conditions, determined the engine operating parameters that were measured and recorded, and the concentration of the mixture of diesel oil and alcohol (n-butanol). It was assumed that the tests will be carried out on the SULZER 6Al 20/24 marine engine installed in the Laboratory of the Engine Room Exploitation. The engine is loaded with a drag torque by means of a Froude water brake Napier C045/C. The test conditions included the values of the angular velocity of the crankshaft, and the values of the engine load with the torque. It was assumed that tests will be carried out for the following rotational speed of the crankshaft: 600,675 and $750 \mathrm{rpm}$. The adopted torque values are: 1, 2.80, $4.65 \mathrm{kNm}$. It has been assumed, that the measurements for each of the torque, and rotational speed values will be performed for the following mass concentration values of the fuel F75, and alcohol (n-butanol):

- $100 \%$ fuel, and 0\% alcohol (mass fractions: $87 \%$ carbon, and $13 \%$ hydrogen),

- $85 \%$ fuel, and $15 \%$ alcohol (mass fractions: carbon $83.67 \%$, hydrogen $13.09 \%$, and oxygen $3.24 \%$ ),

- $70 \%$ fuel, and $30 \%$ alcohol (mass fractions: carbon $80.34 \%$, hydrogen $13.18 \%$, and oxygen $6.48 \%$ ).

It was assumed, that the following engine energy parameters will be measured during the tests:

- indicated pressure,

- crankshaft rotational speed,

- hourly fuel consumption,

- concentrations of: carbon monoxide, carbon dioxide, nitrogen oxides, and oxygen,

- location of the engine fuel rail,

- turbo speed,

- boost pressure,

- exhaust gas temperature at the exit from the engine cylinders, at the entrance, and exit of the turbine of the turbocompressor,

- cylinder supply air temperature (downstream of the water cooler),

- air volume flow supplied the engine.

Measurements of all the above-mentioned parameters, except for the indicated pressure, were carried out with the sampling frequency of $1 \mathrm{~Hz}$, and a resolution of $12 \mathrm{bit}$. The indicated pressure was measured with a frequency of 10 $\mathrm{kHz}$, and a resolution of 12 bits. On the basis of the indicated pressure measurement, the following were calculated: average indicated pressure, maximum combustion pressure, compression pressure, indicated power. The research plan is presented in Table 1.

\begin{tabular}{|c|c|c|c|c|c|c|c|c|c|c|}
\hline \multirow{3}{*}{$\begin{array}{c}\text { Number } \\
\text { of mea- } \\
\text { sure }\end{array}$} & $600 \mathrm{rpm}$ & 1 & 2 & 3 & 4 & 5 & 6 & 7 & 8 & 9 \\
\hline & $675 \mathrm{rpm}$ & 10 & 11 & 12 & 13 & 14 & 15 & 16 & 17 & 18 \\
\hline & $750 \mathrm{rpm}$ & 19 & 20 & 21 & 22 & 23 & 24 & 25 & 26 & 27 \\
\hline \multicolumn{2}{|c|}{ n-butyl content [\%] } & 0 & 13 & 26 & 0 & 13 & 26 & 0 & 13 & 26 \\
\hline \multicolumn{2}{|c|}{ Torque [kNm] } & \multicolumn{3}{|c|}{1} & \multicolumn{3}{|c|}{2.80} & \multicolumn{3}{|c|}{4.65} \\
\hline
\end{tabular}

An original device developed at the Polish Naval Academy was used to measure the indicated pressure. It uses the KISTLER type 7613B transducer. The crankshaft speed is measured with an inductive sensor (the model tests used the rotational speed of the crankshaft calculated on the basis of the indicated pressure measurements). Hourly fuel consumption was measured with a weighing device. The TESTO 350-Maritime analyzer was used to measure the concentration of carbon monoxide, carbon dioxide, nitrogen oxides, and oxygen. The measurement of the position of the engine's fuel rail was carried out using a proprietary device based on a linear potentiometer. The rotational speed of the turbocharger was measured with a magnetoelectric device. A strain gauge transducer was used to measure the boost pressure. Temperature measurements were made using thermocouples. The list of measured parameters, measuring ranges of the instruments used and the measurement accuracy are grouped in Table 2 . 
Table 2. Parameters of the measuring system of the SULZER engine, type 6AL 20/24

\begin{tabular}{|l|c|c|c|c|}
\hline Parameter & $\begin{array}{c}\text { Scope of } \\
\text { measure. }\end{array}$ & $\begin{array}{c}\text { Measuring } \\
\text { accuracy } \\
{[\%]}\end{array}$ & $\begin{array}{c}\text { Sampling } \\
\text { frequency } \\
{[\mathrm{Hz}]}\end{array}$ & Converter type \\
\hline $\begin{array}{l}\text { Indicated } \\
\text { pressure }\end{array}$ & $25 \mathrm{MPa}$ & 0.1 & 20000 & piezoelectric \\
\hline $\begin{array}{l}\text { Crankshaft } \\
\text { rotational speed }\end{array}$ & $\begin{array}{c}8000 \\
\mathrm{~min}^{-1}\end{array}$ & 0.1 & 1 & inductive \\
\hline $\begin{array}{l}\text { Hourly fuel } \\
\text { consumption }\end{array}$ & $100 \mathrm{~kg} / \mathrm{h}$ & 1 & {$[-]$} & gravimetric \\
\hline $\begin{array}{l}\text { Concentrations } \\
\text { of toxic com- } \\
\text { pounds }\end{array}$ & $\begin{array}{r}\text { According to the specification of the TESTO 350- } \\
\text { MARITIME device (all measurements meet the MAR- } \\
\text { POL Annex VI standard) }\end{array}$ \\
\hline $\begin{array}{l}\text { Location of the } \\
\text { fuel rail }\end{array}$ & $100 \mathrm{~mm}$ & 1 & 1 & potentiometric \\
\hline $\begin{array}{l}\text { Turbocharger } \\
\text { rotation speed }\end{array}$ & $\begin{array}{c}40000 \\
\text { min }^{-1}\end{array}$ & 0.5 & 1 & magnetoelectric \\
\hline $\begin{array}{l}\text { The boost } \\
\text { pressure }\end{array}$ & $0.25 \mathrm{MPa}$ & 1 & 1 & strain gauge \\
\hline $\begin{array}{l}\text { Exhaust gas } \\
\text { temperatures }\end{array}$ & $873 \mathrm{~K}$ & 0.3 & 1 & thermocouple \\
\hline Air temperature & $373 \mathrm{~K}$ & 0.3 & 1 & resistance \\
\hline $\begin{array}{l}\text { Air volume } \\
\text { flow }\end{array}$ & $2600 \mathrm{~m}{ }^{3}$ & 1.5 & 1 & Von Karman effect \\
\hline
\end{tabular}

\section{Findings}

In accordance with the proposed research program, both empirical, and model research were carried out in accordance with the described research plan. In the case of model tests, the number of parameters used to assess its adequacy was reduced (in relation to the measured parameters) to [11]: the value of the indicated pressure, and derivative parameters, as well as the excess air coefficient. On the other hand, indicated power, rotational speed, and boost pressure were input parameters to the mathematical model.

The adequacy of the mathematical model was assessed with the selection of the input parameters of the model, so that they correspond to the parameters of the modeled engine:

- connecting rod length,

- length of the crank,

- combustion chamber volume,

- cylinder diameter,

- material parameters used to calculate heat transfer,

- the mass of individual elements performing reciprocating and rotary motion,

- opening and closing angles of intake and exhaust valves,

- injection advance angle, ignition delay angle,

- the number and diameter of the injector holes,

- supercharging parameters.

Then, the measures used to assess the model adequacy were selected. As in the case of previous diagnostic tests $[11,12]$, these were:

- excess air factor $\lambda$,

- hourly fuel consumption Ge,

- measure $\mathrm{K}$ characterizing the similarity of indicated pressure courses, as a function of the crankshaft rotation angle [16].

Based on the experience obtained as a result of model, and empirical research (research for diagnostic purposes), it was assumed that the relative values of the measures should not exceed:
- $20 \%$ for the excess air ratio $\lambda$,

- $10 \%$ for hourly fuel consumption Ge.

On the other hand, the measure $\mathrm{K}$ should not reach a value greater than 10 .

The value of the $\mathrm{K}$ measure was defined as $[11,12]$ :

$$
\mathrm{K}=1-\frac{\mathrm{S}_{1}}{\mathrm{~S}_{2}}
$$

where: $S_{1}=\int_{0}^{720} p_{\text {SCmodel }}(\alpha) d \alpha, S_{2}=\int_{0}^{720} p_{\text {SCmeasure }}(\alpha) \mathrm{d} \alpha$ where: $S_{1}=f(\alpha)$ - area under the diagram of the averaged pressure course indicated as a function of the crankshaft rotation angle for a real object, $S_{2}=f(\alpha)$ - area under the indicated pressure graph as a function of the crankshaft rotation angle for the model.

The value of the $\mathrm{K}$ parameter is a function of the crankshaft rotation angle. It is used for analysis within a limited range of angles corresponding to the highest pressure values (including combustion pressure), i.e. from the injection opening angle to the exhaust valve opening angle.

After selecting the input parameters of the model, simulations, and empirical tests were carried out for the load, and the nominal rotational speed when the engine was powered with diesel oil without alcohol addition. After verifying, that the empirical, and model-based results meet the adequacy requirements, further research was started. Figure 2 shows the course of the indicated pressure as a function of the angle of rotation of the engine crankshaft obtained during the described tests. The course of the integral curves of the indicated pressure for model and empirical tests is shown in Fig. 3. The course of changes in $\mathrm{K}$ parameter is shown in Fig. 4. The test results are presented in Table 3. Table 4 summarizes the relative values of the engine model adequacy measures for the conducted test.

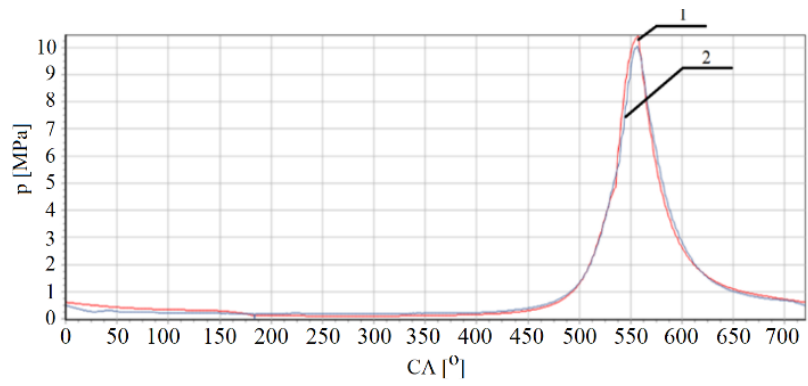

Fig. 2. The course of the indicated pressure obtained as a result of model tests -1 , and empirical tests -2 as a function of the angle of rotation of the crankshaft

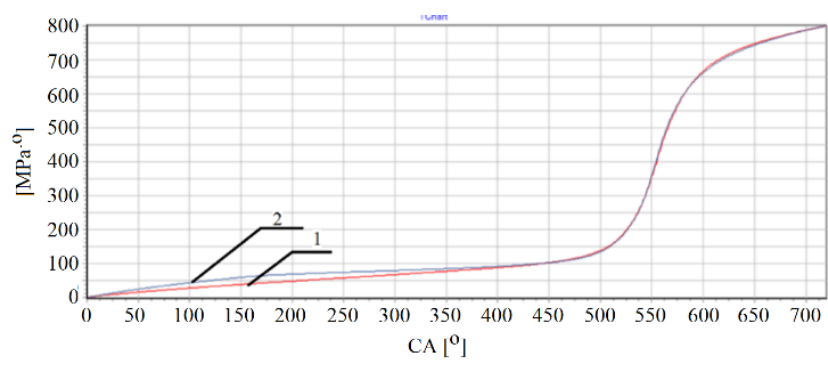

Fig. 3. The course of the indicated pressure integral curves obtained as a result of model tests -1 and empirical tests -2 as a function of the angle of rotation of the crankshaft 


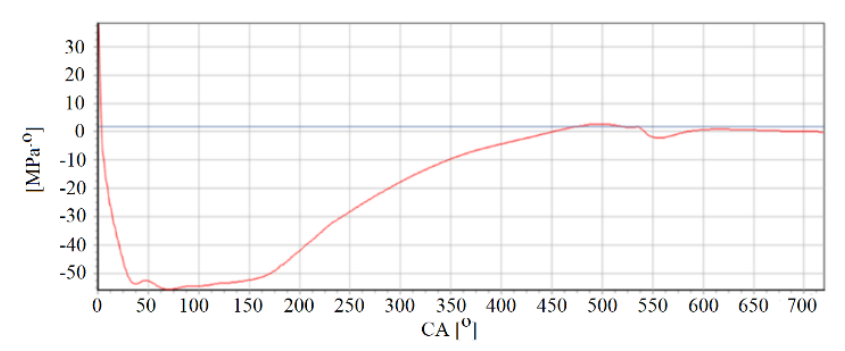

Fig. 4. Course of $\mathrm{K}$ measure

Table 3. Summary of the results obtained as a result of model, and empirical tests for an engine operating at a rotational speed of $750 \mathrm{rpm}$ and a load of $5.12 \mathrm{kNm}$

\begin{tabular}{|l|c|c|c|c|}
\hline & $\begin{array}{c}\text { Indicated } \\
\text { power }\end{array}$ & $\begin{array}{c}\text { Indicated } \\
\text { maximum } \\
\text { pressure }\end{array}$ & $\begin{array}{c}\text { Hourly fuel } \\
\text { consumption }\end{array}$ & $\begin{array}{c}\text { The air } \\
\text { excess } \\
\text { factor }\end{array}$ \\
\cline { 2 - 5 } & {$[\mathrm{kW}]$} & {$[\mathrm{MPa}]$} & {$[\mathrm{kg} / \mathrm{h}]$} & {$[-]$} \\
\hline $\begin{array}{l}\text { Model } \\
\text { research }\end{array}$ & 438.1 & 10.02 & 1397 & 1.42 \\
\hline $\begin{array}{l}\text { Empirical } \\
\text { research }\end{array}$ & 438 & 10.11 & 1487 & 1.42 \\
\hline
\end{tabular}

Table 4. Relative values of measures of model adequacy for an efficient engine

\begin{tabular}{|l|c|c|c|c|}
\hline & $\begin{array}{c}\text { Indicated } \\
\text { power }\end{array}$ & $\begin{array}{c}\text { Hourly fuel } \\
\text { consumption }\end{array}$ & $\begin{array}{c}\text { The air } \\
\text { excess } \\
\text { factor }\end{array}$ & $\begin{array}{c}\mathrm{K} \\
\text { measure }\end{array}$ \\
\cline { 2 - 5 } & {$[\%]$} & {$[\%]$} & {$[\%]$} & {$[-]$} \\
\hline $\begin{array}{l}\text { The values of the } \\
\text { measures of } \\
\text { adequacy }\end{array}$ & 0.02 & 0.89 & 6.4 & 2.17 \\
\hline
\end{tabular}

The analysis of the results of the study included in Table 3 , and the measures of adequacy in Table 4 allowed for the transition to the next stage. It consists in assessing the adequacy of the mathematical model of a ship engine when it is powered by a mixture of diesel oil, and n-butyl alcohol.

The next step was to assess the adequacy of the mathematical model of the marine engine powered by mixtures of diesel fuel with n-butanol. The research was conducted in accordance with the adopted research plan contained in Table 1. The results of the measurements are grouped in Table 5. The values of the adequacy measures for the model are presented in Table 6. In Table 5, the results obtained as a result of empirical tests are marked in gray. However, the results obtained as a result of model tests are marked in blue. The values of rotational speed and indicated power (calculated on the basis of the analysis of the measured indicated pressure) are marked in gray in Table 5. They are input parameters to the mathematical model.

The results of model and empirical tests presented in Table 5, and the values of adequacy measures contained in Table 6 allowed for the recognition of the model as adequate in the entire scope of the research conducted. Earlier studies (conducted for the purpose of developing a diagnostic method) showed that the model is inadequate in terms of rotational speeds of up to $600 \mathrm{rpm}$ and no-load operation) [10]. This allows the conclusion that also in the case of the currently conducted tests, the model may be inadequate for low torque loads and for low rotational speeds.

In the case of previously conducted tests, it was shown that the inadequacy was most likely due to the simplifications used in the model, and the fact that the marine engine (fuel dose and injection advance angle) was adjusted for nominal loads and rotational speeds of its crankshaft.

Table 5. Results of the conducted research

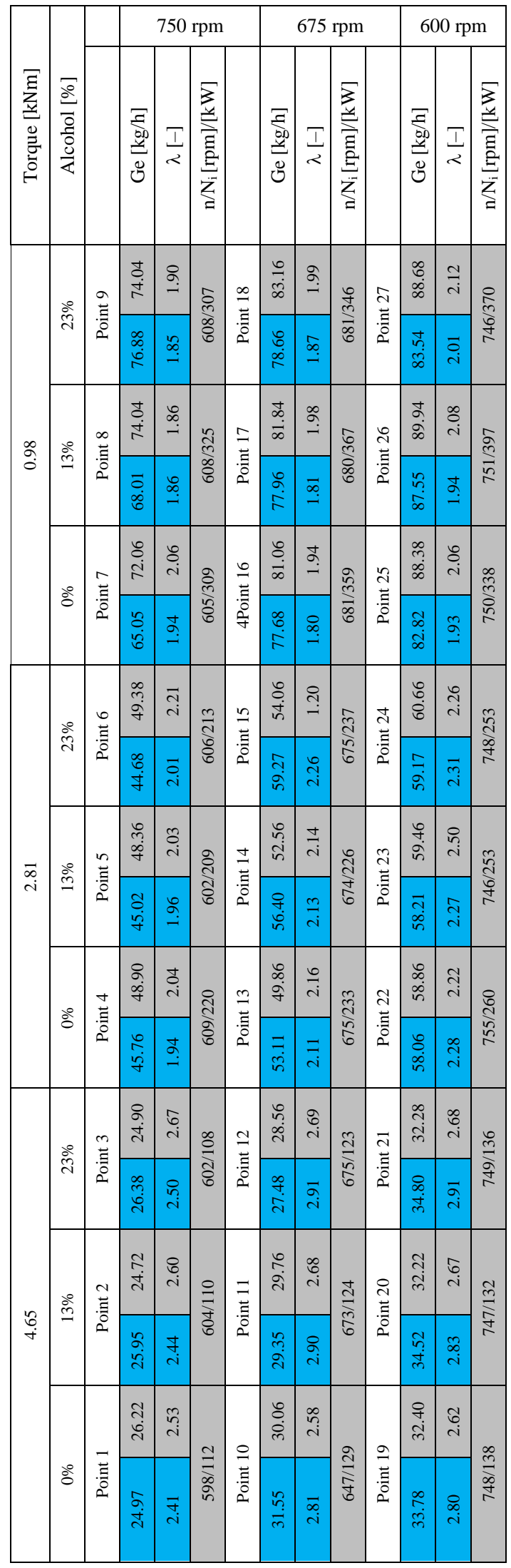


Table 6. Values of measures of adequacy of the mathematical model

\begin{tabular}{|c|c|c|c|c|c|c|c|c|c|c|c|c|c|}
\hline \multirow{2}{*}{ 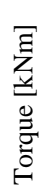 } & \multirow{2}{*}{ 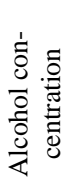 } & \multicolumn{4}{|c|}{$750 \mathrm{rpm}$} & \multicolumn{5}{|c|}{$675 \mathrm{rpm}$} & \multicolumn{3}{|c|}{$600 \mathrm{rpm}$} \\
\hline & & ت. & $\frac{I}{\Delta}$ & $\frac{\sqrt{2}}{3}$ & $\frac{\sqrt{2}}{2}$ & & $\frac{I}{V}$ & $\frac{\sqrt{2}}{3}$ & $\frac{\sqrt{2}}{2}$ & & $\frac{T}{V}$ & $\frac{5}{5}$ & $\frac{\sqrt{2}}{2}$ \\
\hline \multirow{3}{*}{$\stackrel{\infty}{a}$} & $\stackrel{\partial}{\partial}$ & $\begin{array}{l}\stackrel{9}{\circ} \\
.0 \\
0\end{array}$ & $\stackrel{\sim}{\stackrel{c}{r}}$ & \begin{tabular}{l}
\multirow{\infty}{*}{} \\
$\dot{r}$
\end{tabular} & $\begin{array}{l}\mathfrak{n} \\
\dot{m}\end{array}$ & $\begin{array}{l}\stackrel{\infty}{\leftrightarrows} \\
\stackrel{0}{0} \\
.\end{array}$ & \begin{tabular}{l}
\multirow{\infty}{\infty}{} \\
$\infty$
\end{tabular} & $\begin{array}{l}\vec{\nabla} \\
\dot{v}\end{array}$ & ڤి & 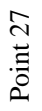 & $\stackrel{n}{n}$ & $\frac{9}{i n}$ & mี \\
\hline & $\stackrel{8}{m}$ & $\begin{array}{l}\infty \\
\stackrel{\infty}{0} \\
\stackrel{0}{0}\end{array}$ & $\underset{\dot{m}}{\sigma}$ & 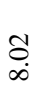 & $\frac{n}{i}$ & $\begin{array}{l}\text { 글 } \\
\stackrel{0}{0} \\
0\end{array}$ & $\begin{array}{l}\infty \\
\infty \\
\infty\end{array}$ & $\underset{+}{\stackrel{+}{+}}$ & $\begin{array}{l}\infty \\
\stackrel{\infty}{\infty} \\
\infty\end{array}$ & $\begin{array}{l}\stackrel{\circ}{N} \\
\stackrel{0}{\equiv} \\
\stackrel{0}{0}\end{array}$ & $\begin{array}{l}\infty \\
\dot{\infty}\end{array}$ & $\begin{array}{l}\stackrel{0}{0} \\
\stackrel{i}{ }\end{array}$ & $\stackrel{m}{\sigma}$ \\
\hline & ؛̊ & 華 & $\underset{\dot{J}}{\forall}$ & $\stackrel{N}{\stackrel{N}{a}}$ & $\begin{array}{l}\infty \\
\infty \\
\text { ஸे }\end{array}$ & 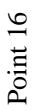 & $\begin{array}{l}0 \\
\infty \\
\infty\end{array}$ & ב & 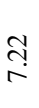 & $\begin{array}{l}\stackrel{n}{7} \\
\stackrel{0}{0} \\
\stackrel{0}{0}\end{array}$ & $\begin{array}{l}\infty \\
m \\
i\end{array}$ & 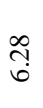 & $\bar{n}$ \\
\hline \multirow{3}{*}{$\begin{array}{l}\infty \\
\stackrel{i}{c}\end{array}$} & $\stackrel{\partial}{\partial}$ & $\begin{array}{l}0 \\
\stackrel{0}{0} \\
0\end{array}$ & $\stackrel{m}{m}$ & $\bar{n}$ & $\begin{array}{l}n \\
0\end{array}$ & $\begin{array}{l}n \\
\stackrel{0}{0} \\
\stackrel{0}{0}\end{array}$ & $\begin{array}{l}\stackrel{0}{0} \\
\text {. }\end{array}$ & $\begin{array}{l}3 \\
\text { aे }\end{array}$ & $\stackrel{⿱ 亠 乂}{\sim}$ & $\begin{array}{l}\underset{\sim}{ \pm} \\
\stackrel{\Xi}{0} \\
0\end{array}$ & $\begin{array}{l}\infty \\
\infty \\
\dot{\gamma}\end{array}$ & $\stackrel{\text { If }}{i}$ & $\stackrel{\widetilde{\sim}}{\mathrm{N}}$ \\
\hline & $\stackrel{8}{9}$ & $\stackrel{n}{\stackrel{0}{0}}$ & 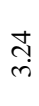 & જ̊ & $\begin{array}{l}\stackrel{n}{n} \\
n\end{array}$ & $\begin{array}{l} \pm \\
\stackrel{\Xi}{\Xi} \\
\stackrel{0}{\Xi}\end{array}$ & $\stackrel{?}{\stackrel{9}{2}}$ & $\vec{n}$ & ச̊. & 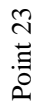 & $\stackrel{\infty}{\dot{\gamma}}$ & $\begin{array}{l}\stackrel{0}{a} \\
\stackrel{i}{*}\end{array}$ & ๙ิ \\
\hline & $\check{g}^{0}$ & $\begin{array}{l}\stackrel{+}{\leftrightarrows} \\
\stackrel{\Xi}{0} \\
.\end{array}$ & $\stackrel{\curvearrowleft}{\dot{\gamma}}$ & $\stackrel{\text { I }}{0}$ & $\underset{\forall}{\vec{\nabla}}$ & $\begin{array}{l}\frac{m}{0} \\
\stackrel{0}{0} \\
0\end{array}$ & $\stackrel{n}{2}$ & กิ & $\begin{array}{l}\stackrel{a}{0} \\
\text { ì }\end{array}$ & $\begin{array}{l}\text { ㄱ } \\
\stackrel{\Xi}{0} \\
0\end{array}$ & 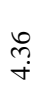 & $\hat{n}$ & 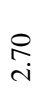 \\
\hline \multirow{3}{*}{$\begin{array}{l}\qquad \underset{0}{0} \\
\dot{f}\end{array}$} & 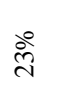 & $\begin{array}{l}m \\
\stackrel{0}{0} \\
\stackrel{0}{0}\end{array}$ & $\stackrel{\infty}{+}$ & $\begin{array}{l}\dot{\sigma} \\
\text { ڤn }\end{array}$ & $\stackrel{\infty}{m}$ & 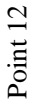 & $\underset{\infty}{+}$ & $\stackrel{r}{\dot{m}}$ & $\stackrel{n}{r}$ & $\begin{array}{l}\vec{N} \\
. \\
\stackrel{0}{0} \\
0\end{array}$ & $\begin{array}{l}3 \\
\dot{n}\end{array}$ & $\underset{\substack{\infty \\
\hdashline}}{ }$ & $\begin{array}{l}\infty \\
n \\
\infty\end{array}$ \\
\hline & $\stackrel{80}{m}$ & $\begin{array}{l}\text { N } \\
.0 \\
\stackrel{0}{0}\end{array}$ & $\stackrel{\curvearrowright}{\curvearrowright}$ & $\hat{a}$ & $\frac{n}{6}$ & 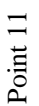 & $\stackrel{\nearrow}{\nearrow}$ & $\hat{n}$ & $\underset{\infty}{\grave{\infty}}$ & 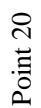 & ฑั & लु. & ڤે \\
\hline & ठ̊ & 苛 & $\stackrel{\Re}{\stackrel{\vartheta}{\forall}}$ & $\underset{\forall}{\stackrel{\gamma}{*}}$ & $\underset{\forall}{\stackrel{+}{\forall}}$ & $\begin{array}{l}0 \\
\stackrel{0}{0} \\
\stackrel{0}{0}\end{array}$ & $\begin{array}{l}\bar{\sigma} \\
\stackrel{i}{ }\end{array}$ & $\stackrel{\check{r}}{\sim}$ & $\vec{\sigma}$ & $\frac{\stackrel{\infty}{0}}{\stackrel{\Xi}{0}}$ & $\stackrel{+}{n}$ & 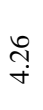 & $\underset{0}{\infty}$ \\
\hline
\end{tabular}

The conducted research has shown that when the engine is running idle, there are very large discrepancies between maximum pressures in individual engine cylinders. They may also result from the applied methodology of indicated pressure measurement. The measurement was carried out individually for each cylinder. This could result in a change in the engine operating conditions during the measurement (fluctuations in the rotational speed of the crankshaft and the engine load with the water brake). This phenomenon was illustrated by presenting a diagram of the maximum pressure for individual cylinders of the engine operating at a rotational speed of $450 \mathrm{rpm}$, and a torque load of 0.42 kNm (Fig. 5). On the other hand, Fig. 6 shows the values of the maximum pressure for the engine operating at a rotational speed of $750 \mathrm{rpm}$, and a load of $4.65 \mathrm{kNm}$.

The discrepancies between the values of the measured and modeled parameters, and what is the result, and the discrepancies in the values of the measures of adequacy, visible in the test results (Table 5) and in the values of the adequacy measures (Table 6):

- the excess air coefficient varies from 0.47 to $9.20 \%$,
- hourly fuel consumption in the range from 1.37 to $9.72 \%$,

- $\mathrm{K}$ measure from 1.70 to $8.84 \%$.

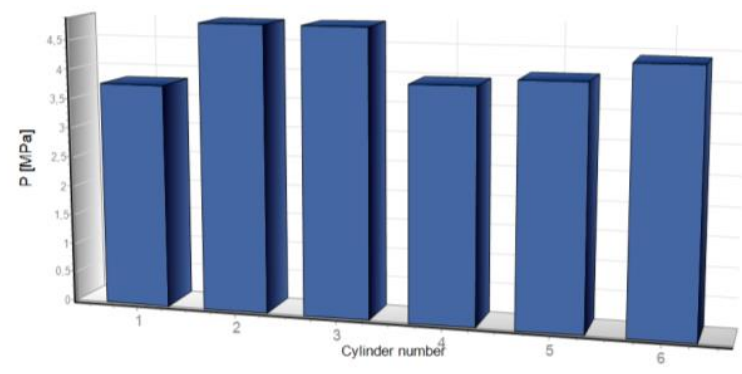

Fig. 5. The values of the maximum indicated pressure for the engine working with the crankshaft rotational speed of $450 \mathrm{rpm}$, and the load of $0.42 \mathrm{kNm}$ (diesel oil)

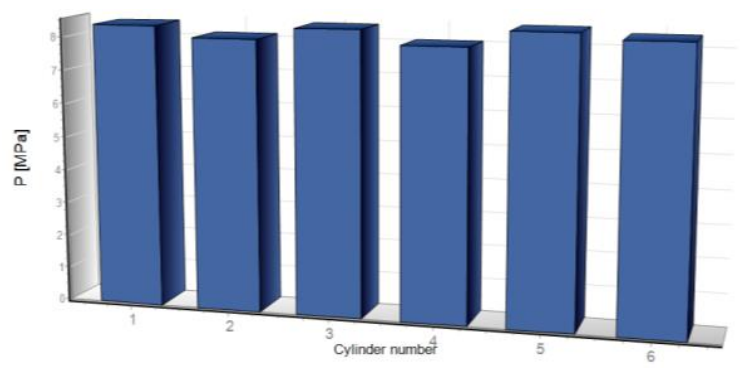

Fig. 6. The values of the maximum indicated pressure for the engine working with the crankshaft rotational speed of $750 \mathrm{rpm}$ and the load of $4.65 \mathrm{kNm}$ (diesel oil)

These fluctuations are randomly distributed and are probably the result of:

- the uniqueness of the processes taking place in the engine cylinders,

- slight influence of the fuel-alcohol mixture used on the measured engine operation parameters,

- the uniqueness of the test conditions for different concentrations of the fuel mixture (inaccuracy of the water brake setting and rotational speed fluctuations introduced by the engine speed controller),

- inaccuracies in indicated pressure measurements caused by wave phenomena occurring in the channels of indicator valves,

- low accuracy of measuring hourly fuel consumption with a weighing instrument (the accuracy of the scale used was $1 \mathrm{~g}$, the measurement was carried out within $60 \mathrm{~s}$ ),

- high inertia of the excess air factor measurement (large length of the measuring channel).

Despite the mentioned sources of measurement errors, it can be observed (in most cases) that the use of different concentrations of the mixture of diesel oil and n-butanol has a noticeable effect on the measured engine operating parameters (Table 5):

- an increase in n-butanol concentration causes an increase in the excess air ratio,

- an increase in the n-butyl alcohol content in the mixture increases the hourly fuel consumption.

Similar relationships can be observed when analyzing the results of empirical research. 


\section{Conclusions}

The results of model and empirical research conducted by the authors and presented have confirmed the adequacy (both qualitative and quantitative) of the developed mathematical model. This justifies its use in research on the use of mixtures of fossil fuels with biocomponents. The use of a mathematical model and a computer program based on it should significantly reduce the amount of empirical research performed. This translates into shortening the time of research and reducing their costs.

Nevertheless, the authors noticed the need to increase the adequacy of the mathematical model (the results of the research are, admittedly, within the adopted ranges of the adequacy measures), which results from the relatively low impact of the use of mixtures of diesel fuel with alcohol. Further research should include:
- applying a smaller calculation step (currently all parameters are counted every 0.1 crankshaft rotation),

- clarification of the heat transfer calculations between the medium and the cylinder walls (now the heat transfer is being modeled. The use of Woschni [7, 8] and Bulaty [1] dependencies in the case of the conducted research resulted in significant errors,

- development of an analytical method for calculating the ignition delay for the mixtures used. The applied method of calculating the release of heat (the heat flux is supplied to the cylinder along with the injected fuel) does not take into account the delay in ignition of the fuel-air mixture (for the needs of the model, this parameter was selected on the basis of empirical tests),

- increasing the repeatability of the test conditions (repeatability of the torque load and rotational speed of the crankshaft).

\section{Nomenclature}

Ge hourly fuel consumption

S surface area

$\mathrm{K}$ measure of similarity

$\lambda$ excess air factor

\section{Bibliography}

[1] BULATY, T. Beitrag zur Berechnung des Wärmeüberganges, insbesondere in längsgespülten, Langhubigen Dieselmotoren. Motortechnische Zeitschrift. 1985, 46(2).

[2] ELFASAKHANY, A. State of art of using biofuels in spark ignition engines. Energies. 2021, 14, 779, 1-26.

https://doi.org/10.3390/en14030779

[3] KNIAZIEWICZ, T., ZACHAREWICZ, M. A physical model of energetic processes in a diesel marine generator set. Combustion Engines. 2018, 57(4), 10-17. https://doi.org/10.19206/CE-2018-402

[4] MURUGESANA, A., UMARANIB, C., SUBRAMANIANC, R. et al. Bio-diesel as an alternative fuel for diesel engines - a review. Renewable and Sustainable Energy Reviews. 2009, 13(3), 653-662.

https://doi.org/10.1016/j.rser.2007.10.007

[5] PAGLIUSO, J. Biofuels for spark-ignition engines. Advanced Direct Injection Combustion Engine Technologies and Development, Gasoline and Gas Engines. 2010, 229259. https://doi.org/10.1533/9781845697327.229

[6] SATISH, K., HYUN, C.J., JAEDEUK, P. Advances in diesel-alcohol blends and their effects on the performance and emissions of diesel engines. Renewable and Sustainable Energy Reviews. 2013, 22, 46-72.

https://doi.org/10.1016/j.rser.2013.01.017

[7] WOSCHNI, G. A universally applicable equation for the instantaneous heat transfer coefficient in internal combustion engines. SAE Technical Paper 670931, 1967.

https://doi.org/10.4271/670931

[8] WOSCHNI, G., KLAUS, B., ZEILIGER, K. Untersuchung des Wärmetransportes zwischen Kolben, Kolbenringen und Zylinderbüchse. Motortechnische Zeitschrift. 1998, 59(9).

[9] YOUNG NO, S. Application of biobutanol in advanced CI engines - a review. Fuel. 2016, 183, 641-658.

\footnotetext{
Marcin Zacharewicz, DSc. DEng. - Faculty of Mechanical and Electrical Engineering, Polish Naval Academy.

e-mail: M.Zacharewicz@amw.gdynia.pl
}

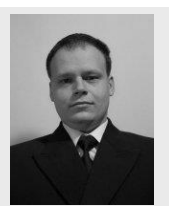

https://doi.org/10.1016/j.fuel.2016.06.121

[10] ZACHAREWICZ, M. Możliwości oceny stanu okrętowego silnika spalinowego o podatności diagnostycznej. AMW. Gdynia 2019.

[11] ZACHAREWICZ, M., KNIAZIEWICZ, T. Mathematical modelling malfunctions of marine diesel engine. MATEC Web of Conferences. 2017, 118, 1-5. https://doi.org/10.1051/matecconf/201711800001

[12] ZACHAREWICZ, M., KNIAZIEWICZ, T. Method of evaluation of the technical condition of the Diesel-electric unit. Diagnostyka. 2019, 20 (2), 113-119. https://doi.org/10.29354/diag/109669

[13] ZACHAREWICZ, M., KNIAZIEWICZ, T., BOGDANOWICZ, A. The use of mathematical model of marine diesel engine in computer program, New Trends in Production Engineering. 2018, 487-493. https://doi.org/10.2478/ntpe-2018-0056

[14] Międzynarodowa konwencja o zapobieganiu zanieczyszczaniu morza przez statki (konwencja MARPOL, tekst jednolity: Dz. U. z 2016 r. poz. 761, z późn. zm.)

[15] Raport: Specjalistyczne badania statystyczne w przemyśle stoczniowym. Stan na 31.12.2019 roku. CTO S.A.

[16] Rozporządzenie ministra gospodarki z dnia 17 grudnia $2010 \mathrm{r}$. w sprawie wymagań jakościowych dla biokomponentów, metod badań jakości biokomponentów oraz sposobu pobierania próbek biokomponentów. Dz. U. 2017.506 t.j.

[17] Rozporządzenie Ministra Infrastruktury i Rozwoju z dnia 7 października 2015 r. w sprawie wymagań dotyczących zawartości siarki w paliwie żeglugowym, w tym sposobu jej oznaczania (Dz. U. poz.1665).

[18] Ustawa z dnia 25 sierpnia 2006r. o biokomponentach i biopaliwach ciekłych. Dz. U. 2020.1233 t.j.

Prof. Tomasz Kniaziewicz, DSc., DEng. - Faculty of Mechanical and Electrical Engineering, Polish Naval Academy.

e-mail:T.Kniaziewicz@amw.gdynia.pl

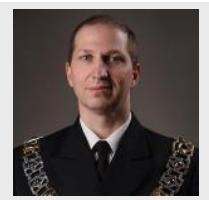

